\title{
Research on Restoration and Renewal Strategy of Traditional Village Landscape Elements_-Taking Xiaodian River Village in Weihui, Henan Province as an Example
}

\author{
Wenjun Zhang, Lei Liu* \\ College of Art and Design, Zhengzhou University of Light Industry, Zhengzhou, China
}

\section{Email address:}

362415812@qq.com (Wenjun Zhang),469231367@qq.com (Lei Liu)

${ }^{*}$ Corresponding author

\section{To cite this article:}

Wenjun Zhang, Lei Liu. Research on Restoration and Renewal Strategy of Traditional Village Landscape Elements_— Taking Xiaodian River Village in Weihui, Henan Province as an Example. Science Innovation. Vol. 6, No. 3, 2018, pp. 149-155. doi: 10.11648/j.si.20180603.16

Received: April 20, 2018; Accepted: May 23, 2018; Published: June 22, 2018

\begin{abstract}
From the perspective of social transformation, the protection and renewal of traditional villages have fallen into the bottleneck of legacy matrix, lack of historical evidence, utilitarianism and modularization. Considering the traditional villages in Henan, where is seriously lack of the material preservation, but the culturalendowments are extremely rich, it is urgent to repair and update them. Based on the methods of cultural landscape and natural geography, the traditional village landscape features are divided into three levels: cultural geography, ethnic area and architectural texture, as well as six restoration elements including the overall pattern, street space, public space node, architectural form, village characteristics, and non material cultural remains. Taking Xiaodian river village as an example, the crux of landscape style is summed up, including four aspects: the deterioration of the natural ecological environment, the change of the traditional street and lane texture, the succession of the old and the old buildings, and the interruption of the historical and cultural heritage. Also the protection and continuation of the whole pattern, the molding and renewal of the building style, the inheritance and accumulation of the traditional culture, and the inward vitality and the digestion strategy are used to restore and update its style.
\end{abstract}

Keywords: Appearance Restoration, Traditional Villages, Landscape Style, Update Strategy, Xiaodian River

\section{对传统村落的景观风貌要素修复与更新策略研究 以河南省卫辉市小店河村为例}

张文君, 刘否

艺术设计学院, 郑州轻工业学院, 郑州, 中国

邮箱

362415812@qq.com(张文君), 469231367@qq.com(刘否)

摘要：社会转型视野下，传统村落的保护与更新陷入了遗存基质残损、史证资料匮乏、功利化与模块化的瓶颈期。 面对河南省传统村落这一物质留存缺失严重、文化禀赋丰厚异常的特殊地域, 修复与更新愈显得刻不容缓。基于文化 景观学与自然地理学的方法, 将传统村落景观风貌分为文化地理、民族区域、建筑肌理三个层级, 以及整体格局、街 巷空间、公共空间节点、建筑形态、村落色彩、非物质文化遗存六个修复要素。以小店河村为实例归纳其景观风貌症 结所在, 包括自然生态环境的恶化、传统街巷肌理的改变、新旧建筑风貌的演替、历史文化传承的中断四大方面, 且 
针对性地提出整体格局的保护与延续、建筑风貌的塑造与更新、传统文化的传承与积淀、内在活力的注入与消化策略 进行其风貌的修复与更新。

关键词：风貌修复, 传统村落, 景观风貌, 更新策略, 小店河

\section{1. 引言}

村落保护第一人冯瀷才先生曾说: “在传统村落里, 有我们民族的记忆和精神传统，有民族的终极价值观，有 民族的DNA和特有的审美，有我们丰富多样的文化创 造。”[1]然而在全球急速工业化和城市化的背景下, 人居 环境发生巨大变化, 以此引发学者对于“传统村落”的高度 关注[2]。在村落风貌呈现出越来越明显的特色泯灭、千城 一面的境况下, 中央提出“要同步保护弘扬传统优秀文化, 延续村落历史文脉, 要融入大自然, 依托现有山水脉络等 独特风光, 让居民望得见山, 看得见水, 记得住乡愁”的 乡村建设思路意义重大[2]。

传统村落景观风貌是传统村落研究的核心内容, 是传 统村落的自然景观和人文景观及其所承载的村落社会、经 济、文化、生态和生活内涵的总和, 具有明显的地域可识 别性。[4]对传统村落的景观风貌修复离不开对地域肌理的 精准辨识, 传统村落不再是一个孤立的景观建筑群, 而是 一个依然活着的、古老的生产单位与生活场域。就河南省 的传统村落而言, 其文化特质与遗存现状都迫使其必须走 依托中原特色的修复与更新道路。

\section{2. 传统村落景观风貌概述}

\section{1. 层级划分}

文化景观特质是经由一个文化群体对自然景观之作用 而形成的。文化是作用者, 自然场域是媒介, 文化地景是 结果 [5]。传统村落的风貌特质并非只是地表外貌或经验上 的物质化客体, 而是一种文化想象或图像再现、解构及象 征环境的方式[6]。作为文化景观的典型代表,传统村落的风 貌构成包含了作为前景的构筑肌理（自然或人工）、作为 中景的文化体系和作为背景的原型因子，原型、文化和肌 理以有机的方式贯穿于地域建构的演化历程之中[7]。传统 村落作为文化景观的典型承载空间, 其风貌构成包含了文 化地理、民族区域和建筑肌理三个层级。文化地理直观地 表达了选址、形式、功能、尺度等空间特征; 民族区域以 地域性、民族性等将传统村落风貌进行了甄别; 建筑肌理 则以丰富的物质形态和灵活的组合模块为代表, 映射在村 落格局、院落布局、空间形态、街巷肌理等范围（表1）。

表1 我国传统村落风貌层级划分。

\begin{tabular}{lll}
\hline \multirow{2}{*}{ 表题 } & 分栏表题 & \\
\cline { 2 - 3 } & 风貌层级 & 类型归属 \\
\hline 1 & 文化地理 & 选址、形式、功能、尺度 \\
2 & 民族区域 & 汉族、侗族、藏族、其他 \\
3 & 建筑肌理 & 格局、院落、空间、街巷 \\
\hline
\end{tabular}

资料来源：作者自绘

\section{2. 修复要素}

对于传统村落景观风貌的修复从整体格局、街巷空间、 公共空间节点、建筑形态、村落色彩、非物质文化遗存现 状等方面展开。整体格局包括选址倾向、建筑肌理、街巷 空间尺度以及标志物等要素, 这些均是村落在历史语境中 环境和时空共同作用下的产物; 村落色彩作为整体格局的 特色和个性气质表达, 对整体风貌也有着重要的影响; 街 巷空间和公共空间节点的典型性、功能性特征, 既可以直 接反应传统村落的风貌特色, 也是村落历史演化的见证和 传统居民的精神寄托; 建筑形态作为村落文化和风貌的核 心表现, 无论是从建筑风格、内部装饰, 还是外观立面和 肌理形态上, 都具备了一定区域内的文脉及空间的传承; 最后，通过对民风民俗、民间艺术及传统手工艺等非物质 文化的挖掘与弘扬, 在很大程度上做到了对不可再生的村 落精神的活态传承与表达（表2）。

表2 传统村落风貌修复要素。

\begin{tabular}{lll}
\hline \multirow{2}{*}{ 表题 } & 分栏表题 & \\
\cline { 2 - 3 } & 修复要素 & 涵盖范围 \\
\hline 1 & 整体格局 & 选址倾向、建筑肌理、街巷尺度及标志物 \\
2 & 街巷空间 & 商业、游憩、生活等视域 \\
3 & 公共空间节点 & 休憩、交流、集会等代表性场所 \\
4 & 建筑形态 & 建筑风格、装饰、立面、肌理 \\
5 & 村落色彩 & 格局、风貌、色彩 \\
6 & 非物质文化遗存 & 民风民俗、民间艺术、传统工艺 \\
\hline
\end{tabular}

资料来源：作者自绘

\section{3. 小店河村景观风貌要素分析}

小店河村位于太行山东麓, 属河南省新乡市卫辉市 管辖。村落由清初迁居此地的闰氏家族倡建, 占地面积 约 5 万平方米, 迄今已有 200 余年的历史。从遗存现状分 析, 小店河村所在的狮豹头乡属太行山基岩山丘区, 自 北向南呈阶梯下降。由于降水、河水侵蚀等自然原因导 致这一地带断层多、山势陡、植被稀、土层薄。早在农 耕文明时期, 村落往往会选择依山傍水的“风水宝地”作 为最早的发源地 [8]。小店河村三面环苍峪山、一面临沧 水, 远观神似一只巨龟俯卧山脊, 头部直指苍河水, 故 有“神龟探水”之称。西北区是间氏家族建设的旧址, 保 留着目前豫北地区较为完整的清代建筑群; 东南区是近 代扩建的新址（图1）。 


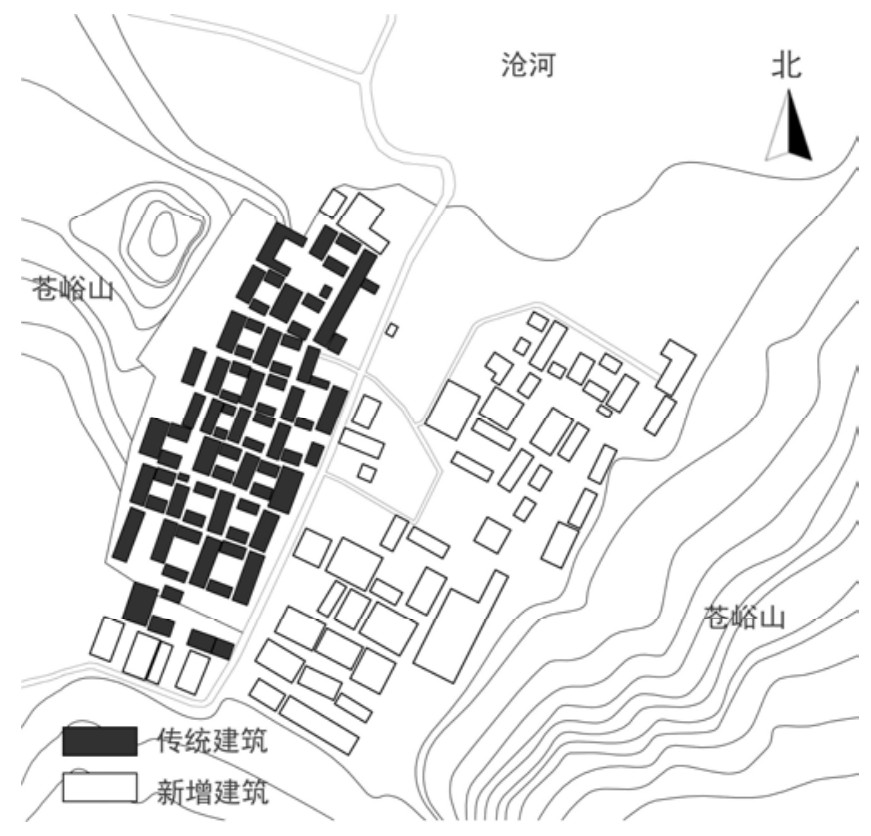

资料来源：作者自绘

图1 小店河村新旧建筑风貌。

\section{1. 空间秩序分析}

\subsection{1. 整体格局分析}

小店河村于清乾隆十三年初成定局, 虽部分建筑受 损，但整体格局依旧特色鲜明，具有一定的历史价值。 保存较为完整的建筑有十座, 共二十八进四合院, 七十 八座房屋。寨门保存完整, 部分寨墙、街巷及标志建筑 的布局遗存状况良好。其中, 十处院落自南向北呈一字 型坐落于龟形高坡之上, 单个院落坐西向东, 自大门至 正房, 依附高坡逐级抬升, 场地内建筑呈现了极强的统 一性与韵律感（图2）。

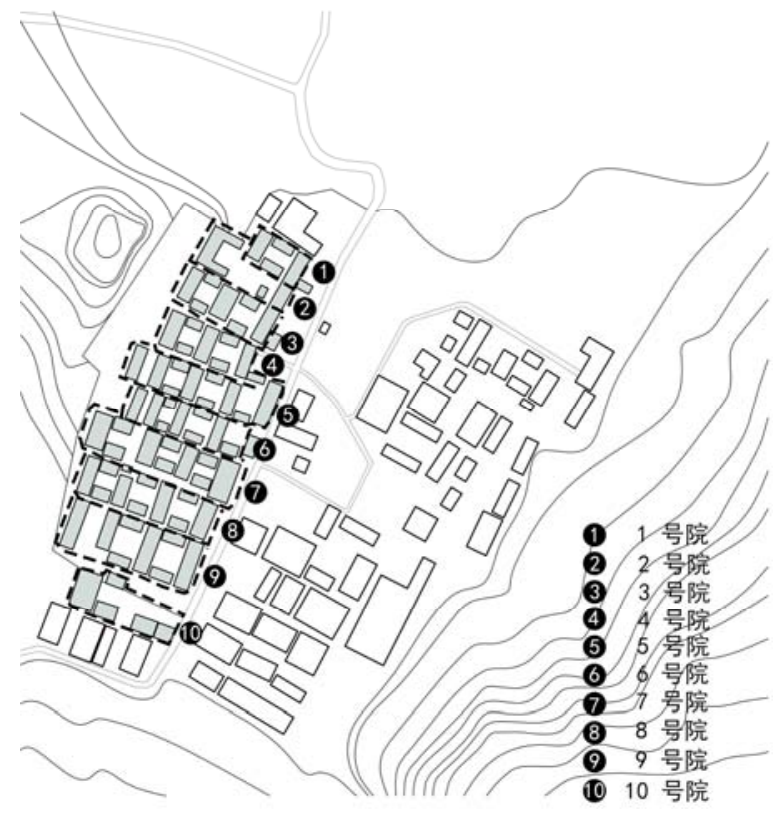

图2 小店河村整体格局。

\subsection{2. 街巷空间分析}

城市的中轴线不仅代表了政治、礼制、军事、交通、 象征等多重含义, 而且是一个城市或城市的营造者对传 统文化理念和精神境界层面的追求 [9]。小店河村由一条 南北走向的主街巷以及若干条纵横交错的小尺度街巷 形态组成。且建筑形式均以正房为中心、以传统工艺烧 制而成的砖为媒介组成基本院落单元。从房屋形态以及 街巷空间的中轴线来看, 轴线本身正是场所的重要功能 区域（图3）。

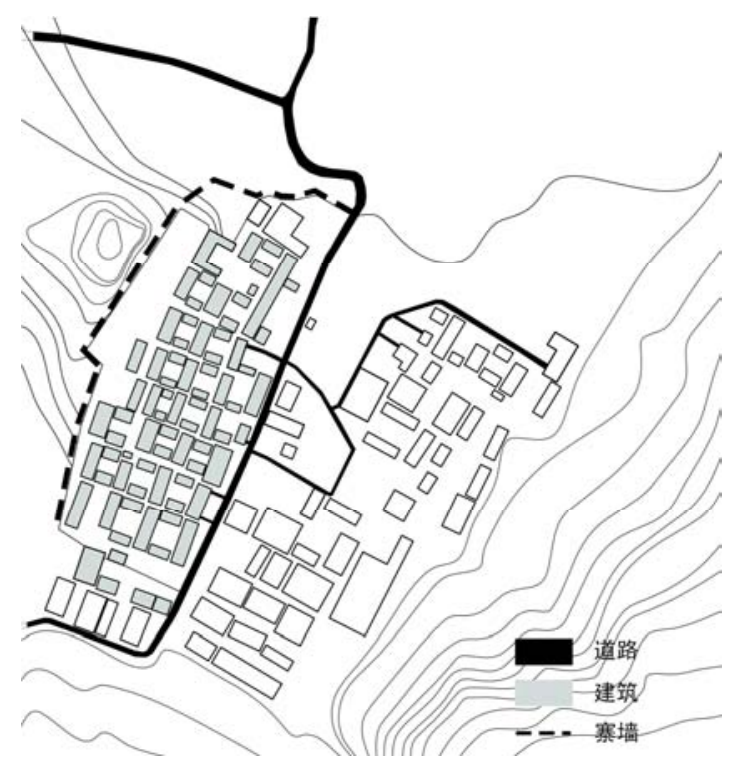

资料来源：作者自绘

图3 小店河村街巷空间。

\subsection{3. 建筑形态分析}

中国古代建筑因其选用建筑材料的性质决定了单体 建筑体量的局限性, 因此古代建筑设计中多是以单体建筑 按照某种序列经过多重组合, 达到某种规模, 规模越大, 建筑群的等级、重要程度越高 [10]。序列的组合拆分, 势 必会产生空间场域。依山而建的小店河村因其堡寨式的村 落格局、独具风水特色的村落选址以及整体风貌的色彩、 材质及建筑细部构造, 均是对豫北山地地区村落选址布局 和单体营建、场域架构的实况反馈。此外, 公共空间场域 由公共建筑院落空间构成, 主要公共建筑的分布也决定了 村落总体场域的空间布局。

\subsection{4. 村落色彩分析}

村落色彩是指公共空间中所有物体外部的色彩总和, 是对总体色彩的概括性感知 [11]。建筑色彩是建筑构成的 关键要素, 也是人们感受最为直观的表现形式, 它体现的 不仅是当地的人文内涵, 也是历史发展的见证[12]。小店 河村的传统民居建筑色彩特色分明, 然而近年来, 随着城 市化与全球化的加速发展, 使传统的地域色彩环境被纷至 沓来的新的建筑群体所覆盖, 功利化、盲目化的建造与拆 除也使小店河村的色彩肌理逐渐被吞噬, 具有民族象征性 的建筑语言濒临消亡。 


\section{2. 空间节点分析}

\subsection{1. 公共建筑}

小店河村聚落的发展是间氏家族分衍的过程，甩氏祠 堂位于整个古建筑群的最北端, 因其特殊的功能使得其建 筑外观与其他传统民居建筑也不尽相同。此祠堂是村落里 唯一一座坐北朝南的公共建筑。祠堂分为三个开间且呈矩 形分布。祠堂既是集中资源和劳动力的经济组织, 又兼具 协调分工、传承文脉的群体空间, 是当时社会和家庭中人 们活动衡量的行为标杆 (图4)。

\subsection{2. 传统民居}

小店河村传统民居格局多为一间、三间、五间、更多 者为七间, 均为奇数, 因奇数在中国传统文化里属阳, 有 阳刚之意。另外奇数间能够保证以明间为中心, 讲求中心 对称布局[13]。小店河村的十座院落是豫北地区保存较为 完好的清代建筑群。但随着城镇化建设的加速发展以及农 村空心化问题的日益严峻, 古建失修、新址重建等都使得 建筑群的修复与保护成为亟待解决的修复难题（图5）。

\subsection{3. 防御构筑}

小店河村由住户院落、街巷路网和居民范围三个层次 组成, 又是由生产生活和防御保护两大功能决定村落的最 终构成。小店河村以四合院住宅为主, 共分为十个院落单 元, 每个院落又分别为二进院、三进院、四进院和五进院, 每座院落均以 3 米高的围墙围合。其中, 院落和院落之间 的街巷尺度在70 100厘米之间，加上围墙（图6），防御 效果极佳。村落入口现存一座坐南面北寨门（图7）, 由 砖石垒砌而成, 结构坚固, 造型独特。

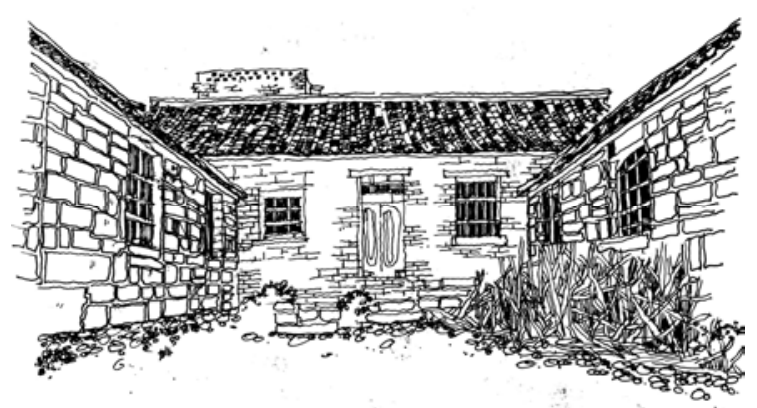

图4 小店河村祠堂。

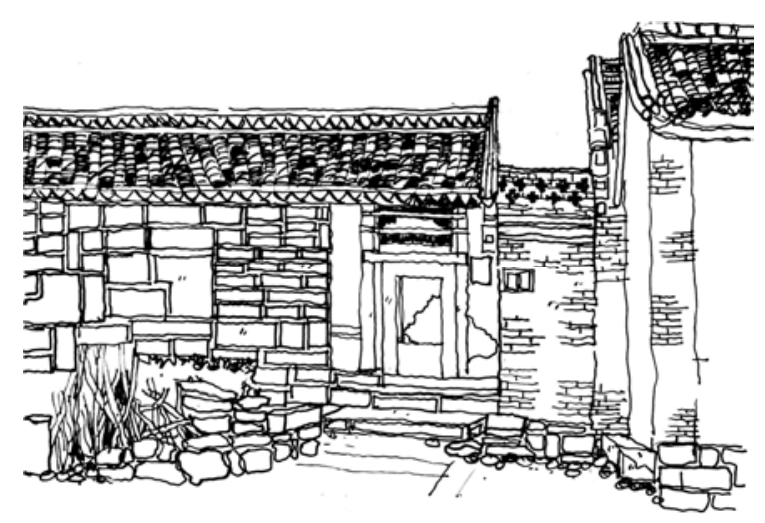

图5 小店河村民居。

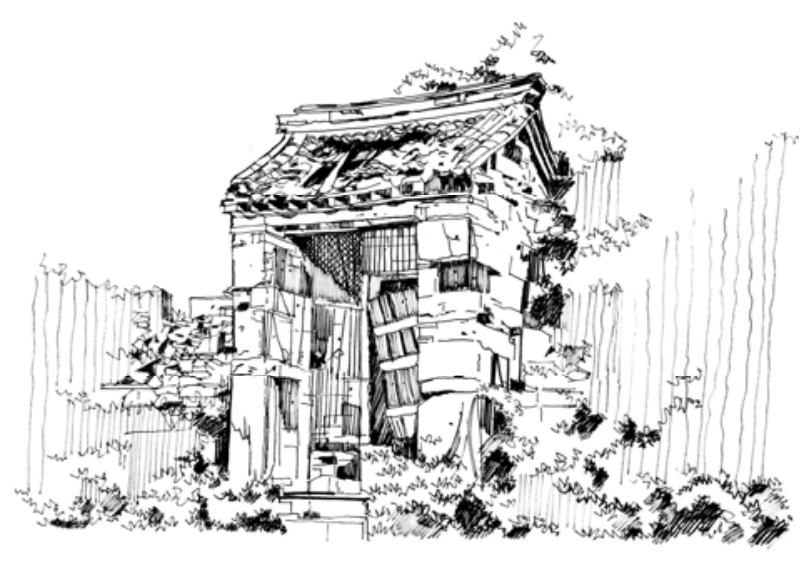

图6 小店河村寨墙。

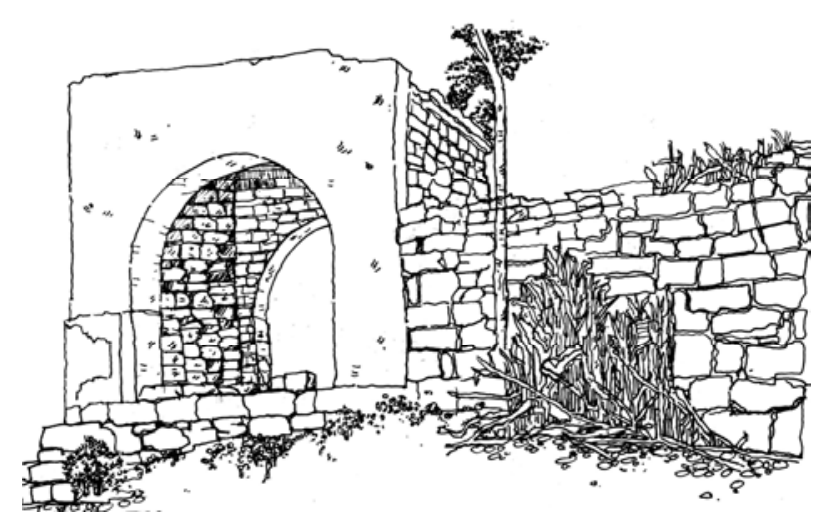

图7 小店河村寨门。

资料来源：作者自绘

\section{3. 非物质文化遗存分析}

基于对自然肌理、人文肌理的修复，可以系统探讨出 中原地区传统村镇向特色小镇培育和转化的景观形态修 复、特征定位修复、建构过程修复以及催化机制修复，并 针对不同地域背景、不同遗存状态、不同开发等级提出相 应的更新措施, 使文化覆盖景观, 使景观反映风貌, 使风 貌根植生活, 使生活体现文化, 使居民对所处环境产生情 感寄托与互动共鸣, 进而对所处地区产生强烈的自豪感和 认同感 $[14]$ 。

\subsection{1. 堡寨文化}

中原地区自古便是兵家必争之地, 长年处于动荡不安 的局面, 因此村落的格局也以堡寨型聚落为主, 以便防御 外来者的侵略。小店河村便是清朝时期修建而成的堡寨式 村落。豫北地区的传统村落多具有辅助性防御体系, 修建 寨墙、寨门、瞭望台等, 与天然屏障互相补充, 形成完整 的防御体系 $[15]$ 。

\subsection{2. 宗族文化}

《尔雅·释亲》中记载: “父之党为宗族”。宗族是中 国传统社会关系中最为核心的亲缘结构, 是基于父系血 缘关系结合而成的亲族群体 [16]。宗族文化作为中国乡 土文脉的重要组成部分, 逐渐转化成一个复杂的生命系 统。在无序的外表下隐藏着高度的秩序与关联, 它是人 
与人之间、人与自然之间通过血缘、地缘紧密联系在一 起 [17], 通过对人们的生产生活、交往教育等方面的影 响, 进而形成了族规、家法、风俗等。而传统村落作为 宗族文化最为明显的社会载体, 在空间布局、组织形式 等方面仍对地缘关系、宗族文化、宗法礼制有所延续。 河南省豫北地区至今仍普遍存在设祠堂祭祖先的行为。 小店河村以间氏祠堂与古民居建筑为代表, 充分展现了 清代建筑的形式与伦理制度。

\subsection{3. 宗教文化}

道教中的风水文化对传统民居的选址及建构有着 潜移默化的影响, 小店河村的选址及布局方式无不体现 着道教文化的熏陶。无论是从传统建筑形式、功能、格 局, 还是从建筑方位、地形地势等方面, 都反映了当时 宗教文化对人们的洗礼, 以及人们对于宗教信仰的膜拜 与敬畏。因此, 对小店河村景观风貌的修复也应与宗教 文化相契合。

\section{4. 修复与更新症结所在及策略探析}

\section{1. 症结所在}

通过上述景观要素的分析, 能够清晰辨识传统风貌的 作用机制, 将空间秩序、物质与非物质相互联结并与既有 开发策略相比照，不难发现其症结所在。

\subsection{1. 自然生态环境的恶化}

小店河传统建筑是我国清代民居建筑的优秀典范, 也 是河南省内为数不多的清代民居文化瑰宝。然而, 小店河 村的实际自然环境现状却不容乐观。景观秩序的混乱、水 域质量的污染、道路通行的不畅以及生活氛围的欠佳都对 其发展和保护带来了极大的难题。

\subsection{2. 传统街巷肌理的改变}

小店河村原是以步行为主要出行方式, 随着城镇化的 加速发展, 汽车等交通工具的不断涌现, 致使村落原本仅 供人与农用生产等工具出行的街巷宽度无法满足当前的 使用需求。街巷、道路的逐渐加宽, 道路宽度与墙体形成 的高宽比例日渐失衡, 乡土气息浓厚的土路变成了水泥路, 小店河村的整体街巷格局虽得以基本保留, 但较原有砖石 铺装仍缺失了与传统风貌相和谐的氛围。

\subsection{3. 新旧建筑风貌的演替}

小店河村清代民居虽是中原地区保存较为完整的建 筑群, 但经过实地调研发现, 当地的政治经济、文化等各 方面的发展仍属于比较落后的状况, 加上当地居民对传统 继承与保护认知的缺乏, 因此对于传统古建的保护与修缙 工作仍存在很多不完善的地方, 造成当前遗存的古民居遭 到了不同程度的损坏。另外, 新增的建筑与传统建筑之间 风貌相差较大, 也使得传统风貌在不同程度上遭到了侵蚀。

\subsection{4. 历史文化传承的中断}

小店河村拥有丰富的传统文化, 分布范围极广, 然而 由于疏于对地域文脉根源的深层考证, 造成了传统文化与 手工艺的消逝。传统村落的建构特征乃是一脉于传统中式 世界观与审美体系的产物, 其选址、形态的演化更是揉融 了“言、象、意”的地域文化提升过程[18], 因此二者不得 剥离分割。

\section{2. 策略探析}

基于对小店河村传统风貌的分析及更新症结的探讨, 总结如下 (图2) 策略, 分别从整体格局、建筑风貌、文 化传承与活力激发四个方面提出调整建议。

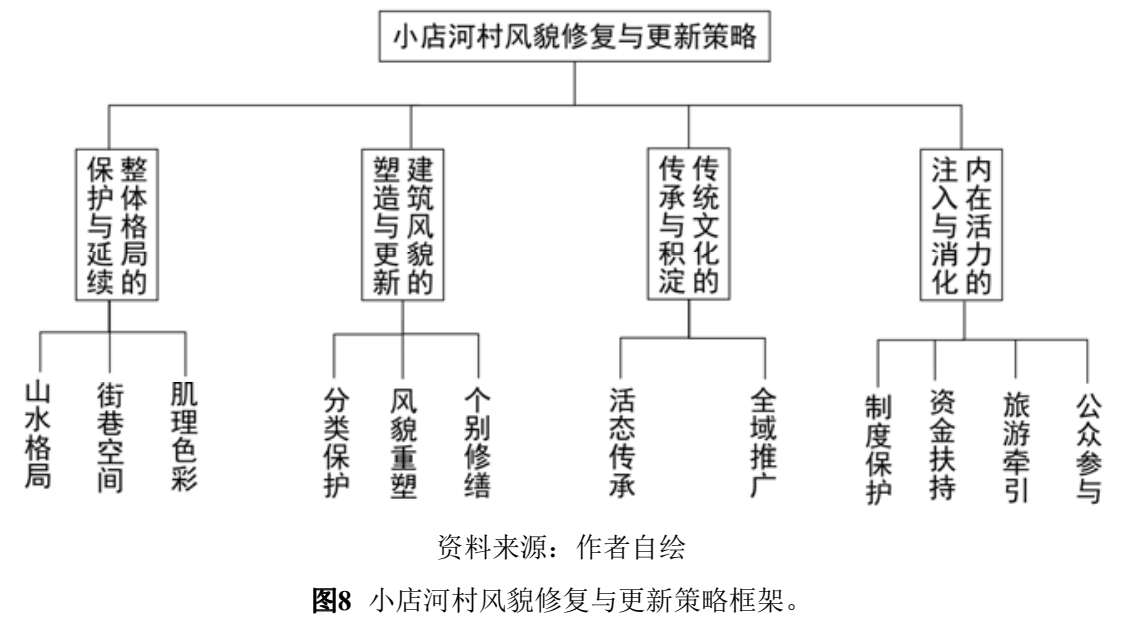

\subsection{1. 整体格局的保护与延续}

从整体出发对小店河村进行环境的治理, 充分尊重和 保护自然生态环境。建立以小店河村清代建筑群为核心的 保护区, 突出小店河村整体风貌格局的延续性, 重点对其 院落空间、街巷肌理、村落色彩、乡风民俗进行有效保护 与传承, 特别注重传统风貌的原真性保护原则; 道路的改
建需要结合整体村落形态特征的历史与现状, 维持固有道 路格局, 切勿大拆大建, 延续村内原有风貌和街巷空间的 宜人尺度, 尤其是主街道两侧建筑的材质、色彩、形态的 严格把控。 


\subsection{2. 建筑风貌的塑造与更新}

小店河村传统风貌修复与更新最重要的即是对建筑 风貌的重塑, 依据既有现状分析, 主要从建筑的整体分类、 传统民居和重点公共空间的修缮等三个方面进行。针对村 内的文物古迹、历史街区、传统民居等分别进行保护、修 葺、再生等整治策略; 对建筑的细节进行精致修复, 对村 内古寨墙、古石磨房、祠堂等公共建筑进行特色要素更新 与保护。

\subsection{3. 传统文化的传承与积淀}

对于小店河村内传统文化的保护应秉持“活态”传承 的原则, 尤其是对那些濒临消失或者尚存活力的非物质文 化遗产, 通过帮扶、发掘发展等有效手段, 加大其传统风 貌的活力续接。在此基础上, 一方面可以制定相关保护制 度, 以此激发村民的保护意识, 一方面可以建立文化博物 馆, 拉动旅游资源, 增加村民收入, 也能促进文化的传承 与发展。

\subsection{4. 内在活力的注入与消化}

小店河村的传统风貌修复与更新, 不仅修复村落传统 风貌的物质载体与文化内核, 更要让传统村落这个生命体 可以不断持续的生长下去。激励是更新的外部推力, 是为 实现既定更新目标而进行的激发和奖励, 在旅游发展背景 下，政府加大宣传，鼓励招商引资和旅游企业投入，激发 广泛的社会参与, 有助于更新[19]。和其他传统村落一样, 小店河村也处在经济发展水平滞后的境地, 制定相应的政 策支持与资金帮扶是不能完全解决问题的。依靠民间的力 量, 加强村民、专业人士、企业的参与, 以及进行产业升 级发展旅游, 会使小店河村焕发新的活力。

\section{5. 结论}

在传统村落、乡村建设等词大热之时, 值得研究者思 忖的, 是如何将这些幸存于现代化发展巨浪之下的传统赋 予历史价值、文化价值和艺术价值, 如何让这些久经风霜 的历史遗存不在国人精神匮乏、压力重创的状态下消失殆 尽。传统村落的修复与利用是需时刻保持敏锐监控的艰巨 工程, 在积极转变审视态度和建设思路的过程中, 最忌发 生因盲目迎合于市场而丢失或“被丢失”掉自身鲜明特色 的现象 [20]。于河南省而言，如何应对遗存基质残损、史 证资料贵乏所造成的村落堙没之势，是保护与开发工作的 核心难点。于小店河村而言, 如何规避千城一面、风貌雷 同所带来的特色掩埋, 是修复与更新策略的关键难题。笔 者通过对小店河村现状及风貌要素进行分析, 找到了症结 并在切实保护村落的既有风貌特色, 充分尊重村落发展的 原真性与时间性，在村落的整体格局大环境的把控制下， 对其进行了可行的策略分析。传统村落作为中华民族巨大 的文化包裹, 容纳了万象的物质与非物质文化遗产, 是我 们民族独特的瑰宝与珍异, 需要更多的研究者与开发者共 同保护。

\section{致谢}

本文为河南省科学技术厅重点研发与推广专项 (科技 攻关）项目: 中原传统村落开发中的参数化空间肌理特征 解析与重构技术研究（182102310963）、2016郑州轻工业 学院博士科研基金资助项目: 遗存残破地区的传统村落肌 理修复与活化策略研究 (2016BSJJ061) 、河南省社科联、 河南省经团联调研课题: 同文化圈层下中原特色小镇的景 观肌理弥合与培育策略研究（SKL-2017-1229）的阶段性 成果之一。

\section{参考文献}

[1] 冯瀷才.传统村落的困境与出路一一兼谈传统村落是另一 类文化遗产[J].民间文化论坛,2013（01）：7-12。

[2] BRUNSKILL R W.Vernacular Architecture: An Illustrated Handbook[M].London: Faber\& Faber, 2000。

[3] 庄霖海.景观风貌规划特色塑造方法探析——连城县城 景观风貌专项规划为例 [J].福建建设科技, 2016(05): 44-45。

[4] 张剑.基于可持续性设计的传统村落景观风貌传承与更新 研究——以烟墩角村为例 [J].装饰, 2017（01）：140-141。

[5] 王纪武. 人居环境地域文化论一以重庆、武汉、南京地区 为例 $[\mathrm{M}]$.南京: 东南大学出版社, 2008。

[6] HAYDEN D.The Power of Place:Urban Landscape as Public History[M].Cambridge:MIT Press, 1995:332-341。

[7] 刘磊.传统村落景观肌理的原型辨识及应用——以河南省 新县西河大湾村为例 [J].地域研究与开发, 2017 (2) 78-82。

[8] 周华庆.陕北城镇空间形态结构演化及城乡空间模式 [J].城 市规划, 2006, 30（2）：39-45。

[9] 柳娜. 韩城古城传统建筑风貌及其特征研究[D].陕西: 西安 建筑科技大学, 2009。

[10] 吕红医, 杨晓林.河南省传统村落保护与利用研究[J].中国名 城，2016（04）：84-89。

[11] 唐莲. 地域性视阈下的蓬安周子古镇景观色彩研究 [J]. 艺术 科技,2016,29(06):335。

[12] 靳凤华.福建古民居建筑色彩区域的地理分布及成因探析 $[J]$.福州大学学报(哲学社会科学版), 2015,29 (04):87-91。

[13] 吴柳琦.河南卫辉小店河传统民居研究[D].陕西：西安建筑 科技大学,2010。

[14] 张文君.中原特色小镇景观肌理弥合策略研究——以巩义 市竹林镇为例 [J].城市地理, 2018（04）：225-226。

[15] 衡秋歌.河南小店河传统民居及村落公共空间保护利用策 略研究[D].北京: 北京建筑大学, 2017。

[16] 孙晓䂀.基于宗族结构的传统村落肌理演化及整合研究 [D]. 武汉：华中科技大学, 2015。 
[17] 张羽.基于文化旅游视角的古村落保护规划——以海口美 孝村为例 $[J]$.安徽建筑, 2016, 23 (01)：74-77。

[18] 刘磊.基于 “簇-群”联结的传统村镇风貌解析与修复一以 李渡口村为例 $[\mathrm{J}]$.中国园林，2018（05）：72-76。

[19] 程海帆,李楠,毛志睿.传统村落更新的动力机制初探——基 于当前旅游发展背景之下[J].建筑学报, 2011(09):100-103。

[20] 刘否. 传统村落的文脉辨识、提炼及应用一以中原地区为 例 [J].世界地理研究, 2017, 26 (1):93-97。

\section{作者简介}

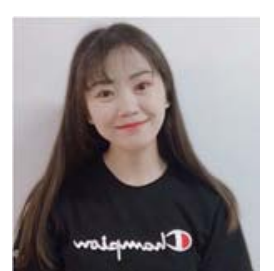

张文君。性别:女、出生: 1991年5月、 民族：汉、籍贯：河南焦作、工作单 位: 郑州轻工业学院、职务: 在读研 究生、主要研究方向: 特色小镇、传 统村落。 